\title{
HIGH - K CALC-ALKALINE GRANITOIDS OF CA. 1 GA. T DM ALONG THE LIMIT PE- AL MASSIF/SERGIPANO FOLD BELT, NE BRAZIL AND THEIR GEOTECTONIC SIGNIFICANCE.
}

\author{
ADEJARDO FRANCISCO DA SILVA FILHO ${ }^{1}$, WILLIAM RANDALL VAN SCHMUS ${ }^{2}$, \\ AND IGNEZ DE PINHO GUIMARÃES ${ }^{1}$
}

\begin{abstract}
The Pernambuco - Alagoas Massif is located in the Southern Domain of the Borborema Province. Sm/Nd isotopic data show the existence of 15 Brasiliano granitic intrusions (ca. $0.6 \mathrm{Ga}$ ) with $\mathrm{Sm} / \mathrm{Nd} \mathrm{T}$ ages ranging from $0.9 \mathrm{Ga}$ to $1.2 \mathrm{Ga}$. They can be divided into two groups: Group 1 includes metaluminous diorites, monzogranites, and granodiorites showing $\mathrm{SiO}$ contents between 60 and 68 wt. $\%$, Na $\mathrm{O}$ $+\mathrm{K} \mathrm{O} \sim 8$ wt. \%, high LILE/HFSE ratios, and spiderdiagrams characterized by troughs at Nb, Sr and Ti. Group 2 comprises peraluminous leucosyenogranites and leuco-monzogranites. They have high $\mathrm{SiO}_{2}(70-75 \mathrm{wt} \%)$, and spidergrams and LILE contents similar to those of Group 1. Both groups show volcanic arc signatures and $\varepsilon N d(t)$ at $0.6 \mathrm{Ga}$ from +3.0 to -1.7 . Granitoids from both groups were generated from sources with similar Sm/Nd signatures. Brasiliano granitoids showing such young Nd isotopic signatures have not been recorded in other domains of the BP. Geochemical and isotopic data suggest mafic underplating during the late Mesoproterozoic or early Neoproterozoic in the Southern Domain of the Borborema Province. The volcanic arc and Nd signatures suggest that the mafic magma may have been a mixture from a subducting oceanic slab ( 1.0 Ga?) and older lithospheric mantle. The mafic magmas differentiated to yield a zoned lower crust, explaining the geochemical differences among the granitoid magmas subsequently derived from it. $\mathrm{T}_{\mathrm{DM}}$ values $<1.0 \mathrm{Ga}$ require later addition of younger juvenile material to the $1.0 \mathrm{Ga}$ lower crust.
\end{abstract}

INTRODUCTION The PE-AL Massif is located in the Southern Domain (Van Schmus et al. 1995) of the Borborema Province, NE Brazil. It is comprised by two high grade metamorphic complexes, respectively Cabrobó and Belém do São Francisco, and by 5 "sensu latu" granitic batholiths (Ipojuca-Atalaia, Jaboatão-Garanhuns, Buique - Paulo Afonso, Águas Belas - Canindé and Marimbondo - Correntes) (Fig. 1). All granitic batholiths are located in the eastern sector of the massif. The Belém do São Francisco complex comprises gray tonalitic/ granodioritic leucocratic gneisses, generally migmatized. The mesosomes are dioritic to tonalitic.

The PE-AL Massif is one of the largest tectonic units of the Borborema Province, being the major unit in terms of granites occurrence. It is bounded in the north by the Pernambuco shear zone and in the south by the Sergipano fold belt paleo suture. Voluminous high-K calc-alkaline granitic batholiths, high-K to shoshonitic and ultrapotassic syenitic/quartz syenitic intrusions, and a varied range of calc-alkaline peraluminous granitic plutons characterize it. A recent survey has showed the existence of 15 granitic intrusions, along the southeastern margin of the PE-AL Massif. They show similar Mesoproterozoic $\mathrm{T}_{\mathrm{DM}} \mathrm{Sm} / \mathrm{Nd}$ model age, but contrasting geochemical composition and facies association. This paper approaches preliminarily their chemical character and significance for the Meso/ Neoproterozoic crustal evolution of the Southern Domain of the Borborema Province.

Geologic Setting The 15 studied plutons are part respectively of the Buique - Paulo Afonso, Águas Belas - Canindé and Marimbondo - Correntes Batholiths (Fig. 1). However they do not comprise continuous granitic area, i.e. they are not "sensu strictu" granitic batholiths. These batholiths were previously considered to be graniticmigmatitic complexes by Brito Neves (1975). Recent regional mapping (Medeiros 1998) identified several syn to late tectonic granitic intrusions within the diatexitic facies of the Belém do São Francisco complex (Fig. 1). Semi - detailed mapping, carried out in key areas, show that syn to late - tectonic peraluminous and metaluminous granitoids, intruding diatexites and metatexites of the Belém do São Francisco complex (Siqueira 1999) are very common. Actually, within the diatexitic areas, granites mainly occur as late tectonic bodies with low angle foliation, emphasizing the importance of the Brasiliano orogeny in the area. The focused intrusions have been divided into 2 broad groups, based on mineralogy and petrography;

GROUP 1 It comprises 08 plutons: Moxotó (PA), Cajueiro (CAJ), Curral Novo (CN), Buique (BUQ), Santana do Mundaú (SMU), Pindoba (PIN) and Tanquinho (TC) (Fig. 1). They occur in the Buique - Paulo Afonso, Águas Belas - Canindé and Marimbondo - Correntes batholiths. The majority of them are bounded by NE-SW faults, with

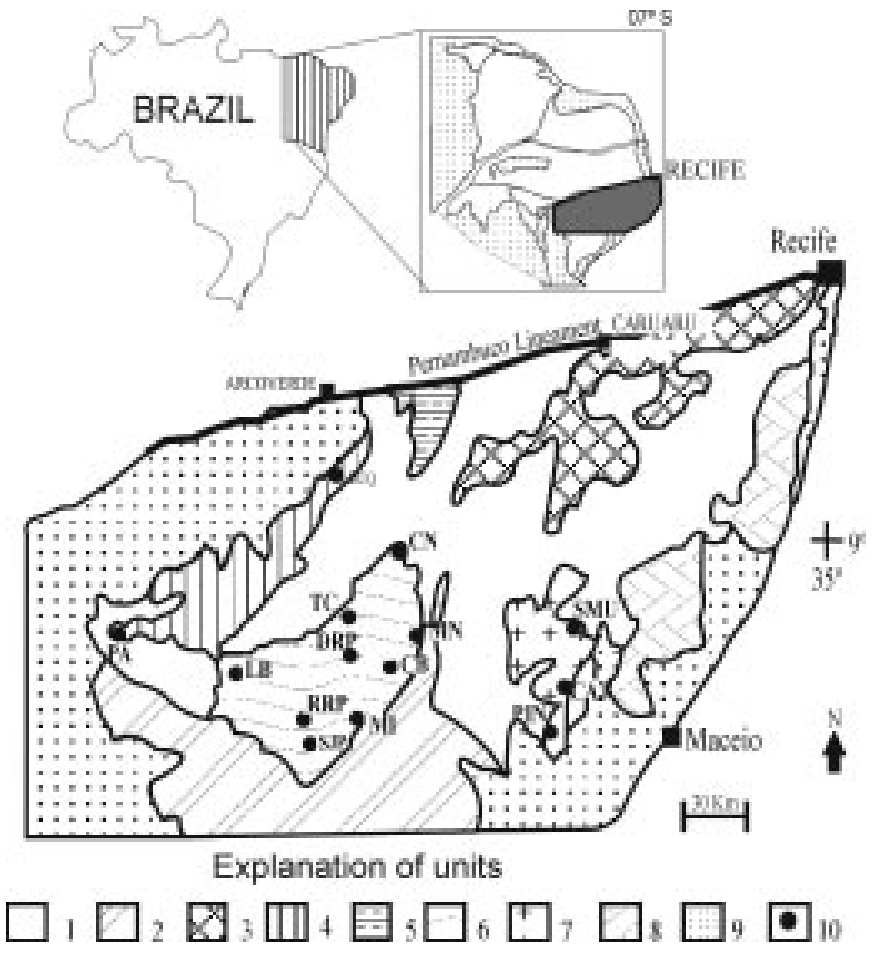

Figure 1-Geological sketch of the PE-Al Massif.

sharp contacts with their country rocks and occupy areas of up to 200 sq. Km. Field relationship in the Tanquinho intrusion show magma mingling features, and low dipping magmatic layering, suggesting the action of low angle tectonics during its emplacement. The Moxotó and Tanquinho intrusions have been cut by brittle shear faults.

Their composition ranges from diorite and granodiorite to monzogranite. Except in the Buique intrusion, they all are porphyritic and very coarse-grained granodiorites containing dioritic enclaves. The phenocrysts are of $\mathrm{K}$ - feldspar up to $5 \mathrm{~cm}$ long. Plagioclase and quartz mainly compose the matrix. The main accessories are \pm biotite, \pm garnet (only in the Moxotó intrusion), \pm amphibole, opaque minerals, sphene, apatite, \pm epidote, zircon, \pm allanite.

GROUP 2 It comprises the Minador do Negrão (MN), Cacimbinhas (CB), Buique (BUQ), Rui Palmeira (RP), Chã Preta (CP), Major

1 UFPE, Departamento de Geologia, Av. Acad. Hélio Ramos, s/n, Cid. Universitária, 50740-530, Recife, PE, Brazil, and CNPq Researcher, e-mail: 56adejar@elogica.com.br

2 Department of Geology, University of Kansas, 2280 Irving Hill Drive, Lawrence, KS, 66045, USA, rvschmus@ukans.edu. 
Isidoro (MI), Dois Riachos (DRP), Lagoa dos Bois (LB) and São José da Tapera (SJT) plutons which occur in the Águas Belas - Caninde and Marimbondo - Correntes Batholiths (Fig. 1). They are highly evolved, porphyritic to equigranular, coarse to medium grained sienogranites and monzogranites. The Pindoba and Major Isidoro intrusions show low angle magmatic foliation. Their accessory phases are biotite, \pm muscovite, zircon, sphene, apatite, \pm epidote and opaque minerals.

WHOLE ROCK GEOCHEMISTRY Major and trace elements were analyzed by ICP-AES, in the ACME Laboratory, Canada, while the $\mathrm{Sm} / \mathrm{Nd}$ isotope analysis were done at the Isotope Geochemistry Laboratory, University of Kansas, following the procedures described by Van Schmus et al. (1995). The A/NK versus A/CNK diagram (Fig. 2-C), $\mathrm{TiO}_{2}$ and $\mathrm{SiO}_{2}$ contents divided the studied granitoids in two groups: Group 1 - metaluminous, $\mathrm{SiO}_{2}$ contents $<70 \%$ (64 to $68 \mathrm{wt} . \%$ ) and higher $\mathrm{TiO}_{2}(0.53-1.12 \mathrm{wt} . \%)$ and Group 2 - weakly peraluminous, showing $\mathrm{SiO}_{2}>70$ wt.\% (70.2 - 74wt.\%) and lower TiO contents $(0.2-0.4 \mathrm{wt} . \%)$. They all show a calc - alkaline trend in the AFM diagram (Fig. 2-B), with the Group2 samples being more alkali-rich. Both groups fall into the field of sub - alkaline rocks in the diagram $\mathrm{K}_{2} \mathrm{O}+\mathrm{Na}_{2} \mathrm{O}$ versus $\mathrm{SiO}_{2}$ (Fig. 2-A) with fields after Irvine and Baragar (1971). The alkali contents $\left(\mathrm{K}_{2} \mathrm{O}+\mathrm{Na}_{2} \mathrm{O}\right)$ are in the 6.9 - 8.8 wt.\% range. The $\mathrm{K}_{2} \mathrm{O} / \mathrm{Na}_{2} \mathrm{O}$ ratios range from 0.84 to 2 characterizing them as high- $\mathrm{K}$ calc-alkaline granitoids. The $\mathrm{Ba}$ contents are similar in both groups (750 and $2300 \mathrm{ppm}$ ). The $\mathrm{Sr}$ and $\mathrm{Zr}$ contents are slightly lower in the granitoids from group 2 , as follows; (1) $\mathrm{Sr}$ contents ranges between 150 and $620 \mathrm{ppm}$ in group 2, and between 400 and 900ppm in group 1; (2) $\mathrm{Zr}$ contents are lower than $200 \mathrm{ppm}$ in the granitoids from group 2, and ranges between 170 and $350 \mathrm{ppm}$ in the group 1 .

The REE patterns of both groups show similar LREE enrichment and lack of significant Eu anomalies (Fig. 3-A). However the patterns of the granitoids from group 2 show higher HREE/LREE ratios with $(\mathrm{La} / \mathrm{Yb})_{N}$ ratios in the $12-25$ range. The $(\mathrm{La} / \mathrm{Yb})_{N}$ ratios of granitoids from group 1 range from 30 to 40 . (Fig. 3-A).

Troughs at $\mathrm{Nb}, \mathrm{Sr}$ and $\mathrm{Ti}$ (Fig. 3-B) characterize the spiderdiagram patterns of the studied granitoids. However, differences between the patterns from the two groups of granitoids do exist and are mainly reflected in the higher contents of HREE (including Y) and deeper troughs at $\mathrm{Ti}$ in the patterns of granitoids of group 2. The $\mathrm{Nb}$ trough is classically ascribed to subduction-related rocks and the $\mathrm{Sr}$ one to plagioclase fractionation, or to low $\mathrm{Sr}$ contents in the source.

Nd ISOTOPIC GEOCHEMISTRY The $\varepsilon N d(0.6 \mathrm{Ga})$ of the whole analyzed sample set ranges between +3 and -1.7 , which are values considered by Van Schmus et al. (1995) as typical of granitoids derived from an ortho derived protholith, without a major upper crust component. The group 1 show eNd $(0.6 \mathrm{Ga})$ ranging from -2.0 to 0.7 . The group 2 show $\varepsilon N d(0.6 \mathrm{Ga})$ ranging from -0.6 to +3.2 . Only one pluton from group 2 (Rui Palmeira) show lower eNd (0.6 Ga) (-1.7). Because the sample was collected close to the external pluton contact, the lower $\varepsilon N d$ could be interpreted as due to wall rock contamination. The figures 4-A and 4-B show a plot of ÎNd values versus $\mathrm{T}_{\mathrm{DM}}$ ages for both groups of granitoids.

The granitoids from group 1 show $\mathrm{T}_{\mathrm{DM}}$ ages $\geq 1.0 \mathrm{Ga}$, while the $\mathrm{T}_{\mathrm{DM}}$ ages of the granitoids from group 2 are mostly $<1.0 \mathrm{Ga}$ which suggests that the protholiths of the granitoids from group 2 had a larger contribution of the Brasiliano juvenile material. Such younger $T_{D M}$ ages have not been described in Brasiliano granitoids from others

A)
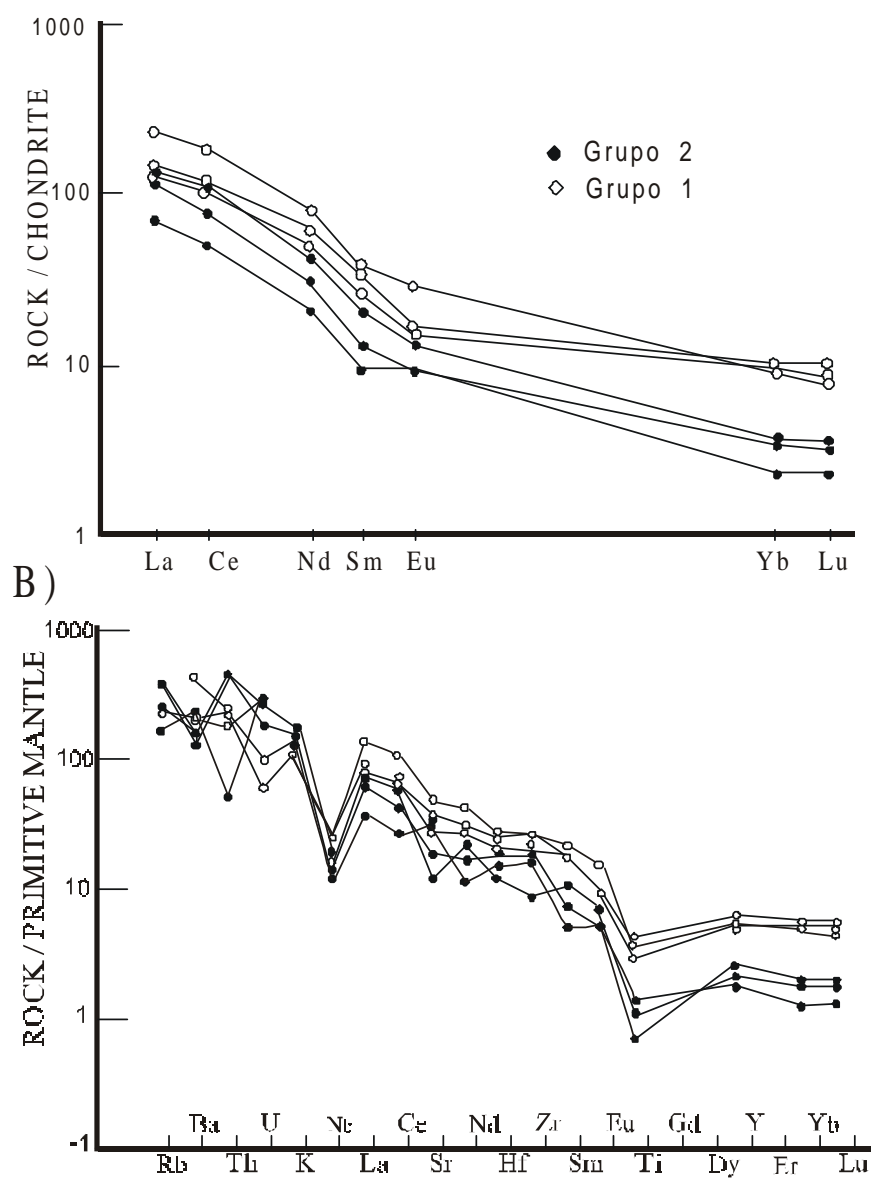

Figure 3-(A) Chondrite normalized REE diagram with Group 1 and Group 2 samples. Open Circles - Group 1. Filled Circles - Group 2; (B) Chondrite normalized spidergram with Group 1 and Group 2 samples. Open Circles Group 1. Filled Circles - Group 2
A)

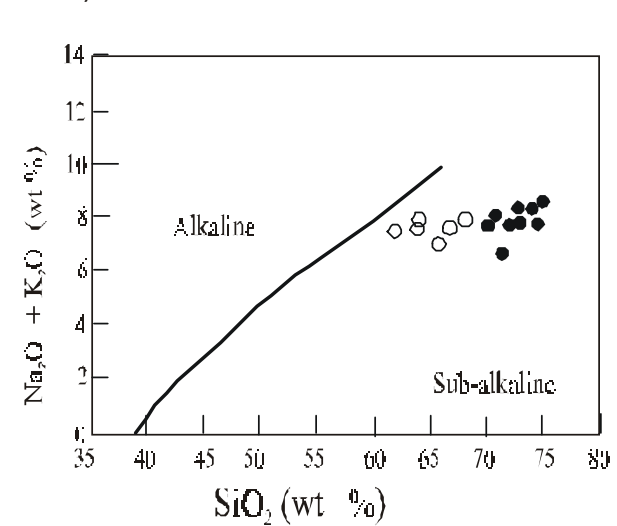

B)

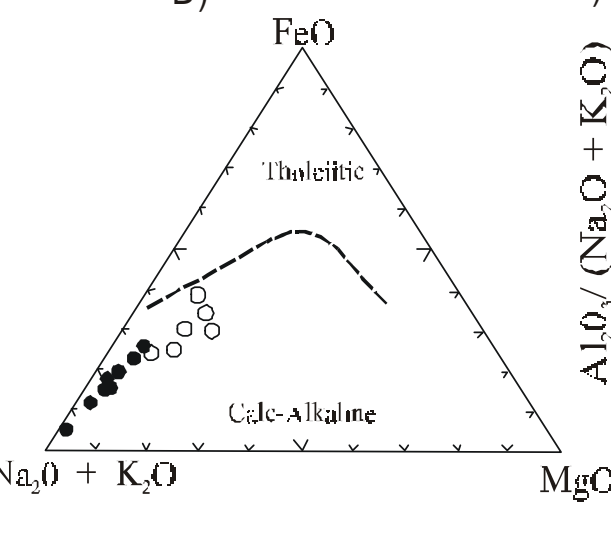

C)

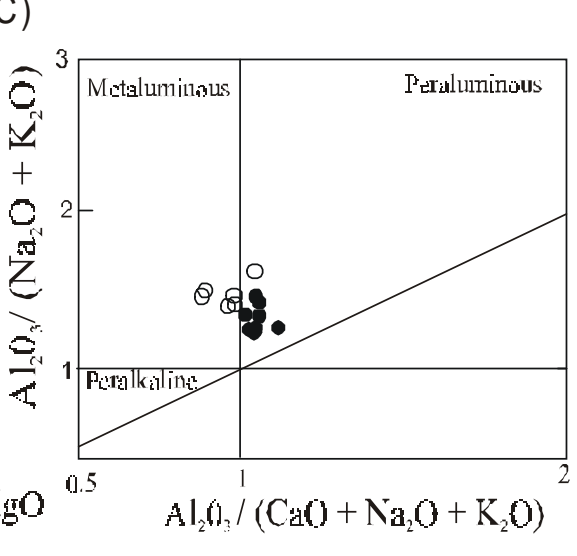

Figure 2-(A) Diagram $\mathrm{Na}_{2} \mathrm{O}+\mathrm{K}_{2} \mathrm{O}$ vs. $\mathrm{SiO}_{2}$ with field after Myiashiro (1968) and study samples. Open Circles - Group 1. Filled Circles - Group 2; (B) AFM diagram after Irvine and Baragar (1971) with study samples. Open Circles - Group 1. Filled Circles - Group 2; (C) Diagram A/NK vs. A/CNK after Shand (1931) with study samples. Open Circles - Group 1. Filled Circles - Group 2. 
A)

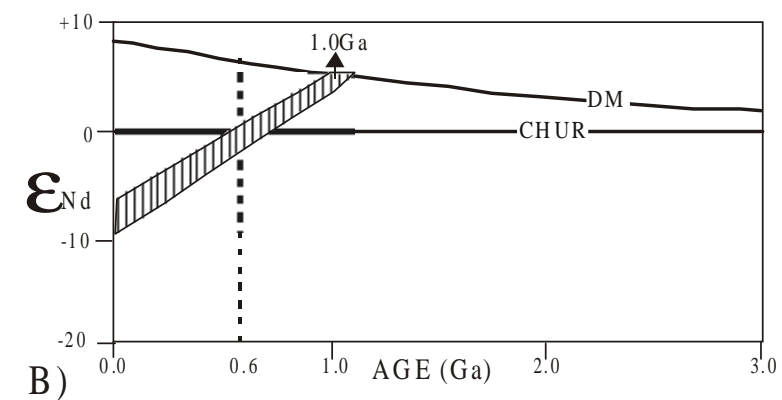

B)

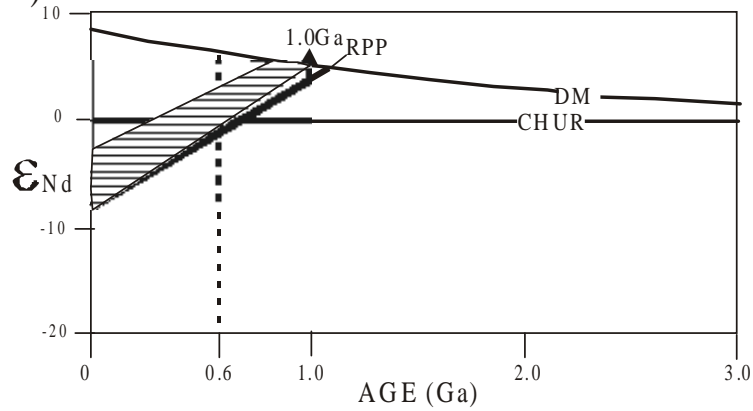

Figure 4-ENd vs. Age (Ga.) diagram. CHUR - Chur isotopic evolution with time. DM - Depleted mantle isotopic evolution with time; (A) The showed envelope is for Group 1 samples; (B) The showed envelope is for Group 2 samples. RPP - Stands for Rui Palmeira pluton sample.

domains within the Borborema Province. A Rb-Sr isochron available for the metaluminous high-K Tanquinho intrusion yields an age of ca. 580 Ma. (Silva Filho et al. 1997), which suggest these granites were not extracted from a Brasiliano juvenile protholith.

DISCUSSION AND CONCLUSIONS Recent petrologic works over the main metaluminous high $-\mathrm{K}$ to shoshonitic granitic suites from the Borborema Province (Silva Filho et al. 1997; Guimarães and Silva Filho 1998, Neves et al. 1998, Mariano et al. 1999) point unanimously to the existence of an upper mantle metasomatized during the Paleoproterozoic, respectively in the Northern, Central and Southern Domains. This paper shows that the high-K calc alkaline granites in the Southern Domain of the Borborema Province could not be generated from a Paleoproterozoic lithospheric mantle.

The granitoids from Group 1 are weakly peraluminous, with some of them being garnet bearing (Moxotó pluton), and show HREE/LREE ratios higher than those recorded in granitoids from group 1 . They could be generated by melting of metapelites, because such composition with $\mathrm{Sm}$ - Nd signatures similar to those recorded in these granitoids have been described in the south at the Sergipano Fold Belt. However, the granitoids from group 1 have low silica contents and they are too rich in $\left(\mathrm{CaO}+\mathrm{Na}_{2} \mathrm{O}+\mathrm{K}_{2} \mathrm{O}\right)$ relative to $\mathrm{Al}_{2} \mathrm{O}_{3}$ to be primary melts of biotite-bearing metasediments. The group 1 granitoids could not represent primary melts of "normal" amphibolites due to high $\left(\mathrm{Na}_{2} \mathrm{O}+\mathrm{K} O\right)$ contents and $(\mathrm{FeO}+\mathrm{MgO})$ relative to $\mathrm{Al}_{2} \mathrm{O}_{3}$ (Patiño Dulce 1995). Thus, melting of a hybrid source may generate the granitoids from group 1 . This source could be either: alkali-rich (metasomatized) garnet bearing amphibolites( Mesoproterozoic) mixed with Neoproterozoic tholeiitic basalts or, Mesoproterozoic greywackes mixed with Neoproterozoic tholeiitic basalts. The low $\mathrm{SiO}_{2}$ contents recorded in these granitoids, disagree with their source from melting of greywackes. (Patiño Dulce 1995).

The chemical signature of the metaluminous high-K calc - alkaline granitoids from Group 2 suggests that they were generated from melting of a lithospheric mantle metasomatized during the Mesoproterozoic.

The source of both groups of granitoids point to a $(1.0 \mathrm{Ga})$ metasomatized mantle along the southern border of the PE-AL Massif.
It means the occurrence of a lithospheric plate, between the Sergipano Fold Belt and the PE-AL Massif. Such plate shows isotopic signature younger than the rest of the Borborema Province.

Lack of evidence for a suture in the area could suggest that a small mafic crust formed during the Mesoproterozoic, related to a small basin, where sediments were deposited to the south/Sergipano Fold Belt. Crustal accretion starts with rifting of a continental crust and then formation of an oceanic crust, continuing later with the consumption of this oceanic crust along a subduction zone and with the formation of magmatic arcs. The present lack of clear evidence of a paleo suture between the PE-AL Massif and the Sergipano Fold Belt, as gravimetric anomalies and ophiolitic complexes, does not rule out a priori this hypothesis, as the identified PE-AL Massif batholiths could be the remnants of an arc. On the other hand, as other authors defend (Van Schmus et al. 1995; Neves et al. 2000), the absence of Brasiliano - age suture zones in the inner part of BP, and the voluminous predominance of I - type granitoids far away from the boundary zones with the adjoining cratons (Silva Filho et al. 1997; Neves and Mariano 1997; Ferreira et al. 1998; Guimarães and Silva Filho 1998) suggests the magmatism is not directly subduction- related. As the southern part of the PE-AL Massif is close to the NE margin of the São Francisco Craton the generation of the study rocks by subduction process should be examined carefully. As they are not juvenile, they should be reworked Cariris Velhos materials, during the Brasiliano continental collision. Up to now we have dated only one pluton, the Tanquinho (Silva Filho et al. 1997), which yields Brasiliano age. However, field relationship clearly points to Brasiliano ages for the studied granitoids.

Group 2 granites are mildly peraluminous, however they do not show either geochemical or mineralogical signature of $\mathrm{S}$ - type granites. So its peraluminous character could have been inherited from orthoderived metamorphic rocks.

There are three hypotheses regarding the isotopic signatures of Group 1 and Group 2 granites;

Reworking of mafic metaigneous (Group 1) rocks. Several authors show that metaluminous granites are usually extracted from metaigneous sources, amphibolitic or eclogitic, with or without a mantle component. The major and trace elements contents of Group 1 plutons Tanquinho, Santana do Mundaú suggest that they have a mantle component. The occurrence of magma mixing features in the Tanquinho intrusion suggests mafic magma interacted with crustal material of similar $\mathrm{T}_{\mathrm{DM}}$.

Reworking of metasedimentary/metavolcanic rocks formed during the Cariris Velhos event at a continental margin, during the Brasiliano collision. The common occurrence of low angle foliation in the Group 2 granitoids suggests that they were intruded during the action of a low angle crustal shortening/collision tectonics.

(3) Mixture of Brasiliano underplated mafic juvenile magma with crust formed during the Cariris Velhos event. The lack of juvenile Brasiliano magma in the area up to now, rule out the hypothesis of partial melt of an older crust, generated during the Cariris Velhos event, triggered by the underplating of juvenile Brasiliano or early Neoproterozoic mafic magma.

(4) Geochemical and isotopic data suggest mafic underplating during the late Mesoproterozoic or early Neoproterozoic in the Southern Domain of the Borborema Province. The volcanic arc and $\mathrm{Nd}$ signatures suggest that the mafic magma may have been a mixture from a subducting oceanic slab $(\sim 1.0 \mathrm{Ga}$ ?) and older lithospheric mantle. The mafic magmas differentiated to yield a zoned lower crust, explaining the geochemical differences among the granitoid magmas subsequently derived from it. $\mathrm{T}_{\mathrm{DM}}$ values $<1.0 \mathrm{Ga}$ require later addition of younger juvenile material to the $1.0 \mathrm{Ga}$ lower crust.

(5) The subduction - related signatures of these granitoids could have been inherited from their source.

Acknowledgements To Allen Fetter and Marianne Kozuch for their technical assistance during the IGL/U. of Kansas isotope analytical work, and to CAPES and CNPq which supported the visits of 2 of us to the IGL. 


\section{References}

Brito Neves B.B. 1975. Regionalização geotectônica do précambriano nordestino. Universidade de São Paulo, Ph.D. Thesis, 200p.

Ferreira V.P., Sial A.N., Jardim de Sá .F. 1998. Geochemical and isotopic signatures of Proterozoic granitoids in terranes of the Borborema structural prov

作 constraints for evolution of the shoshonitic Brasiliano Bom Jardim and Toritana constraints for evolution of the shoshonitic Brasiliano Bom Jardim and Toritam complexes: evidence for a Transamazonian enriched mantle under Borborema

Irvine T.N. \& Baragar W.R.A. 1971. A guide to the chemical classification of the common volcanic rocks. Canadian Journal of Earth Sciences, 8:523-548.

Medeiros V.C. 1998. Folha Garanhuns, escala 1:250.000. CPRM, Programa PLGB Internal Report, Recife, $22 \mathrm{p}$.

Neves S.P. \& Mariano G. 1997. High-K calc-alkalic plutons in NE Brazil: origin of the biotite diorite/quartz monzonite to granite association and implications for the evolution of the Borborema Province. International Geology Review, 39:621-638

Neves S.P., Mariano G., Guimarães I.P., Silva Filho A.F. 1998. Diferenciação intralitosférica e crescimento crustal na Província Borborema durante a orogênese Brasiliana. In SBG, Congresso Brasileiro de Geologia, 40, Belo Horizonte, Anais, 20.

Neves S.P. Mariano G., Guimarães I.P. Silva Filho AF, Melo S.C. 2000. Intralithospheric differentiation and crustal growth: evidence from the Borborema Province, NE Brazil. Geology, in press.
Patiño Douce A.E. 1995 Experimental generation of hybrid silicic melts by reaction of highAl basalt with metamorphic rocks. Journal of Geophysical Research, 100(B8): $15.623-15-639$.

Siqueira 1999. Interface entre o Complexo Cabrobó e o Batólito Águas Belas-Canindé. Graduation Report, UFPE, Recife, 78p.

Silva Filho A.F. Van Schmus W.R., Guimarães I.P. Luna, E.B.A. 1997. Nd signature of PE$\mathrm{AL}$ massif late tectonic granitic rocks, NE Brazil: evidence of sucessive crustal accretion during the Proterozoic. In: South American Symposium on Isotope accretion during the Proterozoic. In: South

Van Schmus W.R., Brito Neves B.B., Hackspacher, P., Babinsky M. 1995. U/Pb and Sm/ $\mathrm{Nd}$ geochronologic studies of the eastern Borborema Province, NE Brazil: initial $\mathrm{Nd}$ geochronologic studies of the eastern Borborema Province, NE
conclusions. Journal of South American Earth Sciences, 8:267-288.

Van Schmus W.R., Brito Neves B.B., Hackspacher P.C., Babinski M., Fetter A., Dantas, E.L. 1997. Application of U-Pb and Sm-Nd geochronology to understanding the geotectonic history of the Borborema Province, NE Brazil, and its implications for the evolution of the West Gondwana. In:South American Symposium on Isotope Geology, São Paulo, Proceedings, 27-30.

Contribuiç̃ão IGC-185 Received March 10, 2000 Accepted for publication May 15, 2000 